\title{
The Assisting Profession's Confrontation with Evil ${ }^{1}$ Jaroslav Kozák, Michal Opatrný
}

Evil $^{2}$ is not normally considered to be an object of activity of assisting professions. Every assisting profession defines "its" object in a specific manner, which may partially differ in different contexts, both conceptually and in content.

For example social work, which is an assisting profession that can easily be associated with confronting evil, defines its object in the Czech environment as coping with dysfunctional interactions of individuals, or groups, families or communities, and their environment. ${ }^{3}$ In German-speaking context the approach to defining the object of social work is partially different. There its object is taken to be coping with social problems. Social problems are taken to mean that e.g. an individual is, on a temporary or long-term basis, incapable of meeting her needs or desires due to her unsatisfactory involvement in the social systems of her environment - because she lacks the necessary competencies, supporting social networks or the power necessary to promote her legitimate demands. ${ }^{4}$ The important point is that the object is coping with social problems, not the problems themselves. What a social problem is can be described and defined by sociology, but the question how to cope with it must be answered by social work. ${ }^{5}$ The theoretical definitions of social work mostly differ from what its object is taken to be in practice. In contemporary Czech context of social work practice a social worker is mostly not expected to "bridge" the gap between people in trouble and the society, but to solve the unsatisfied needs of people with the help of social services and so-called social benefits. ${ }^{6}$

The theological and philosophical point of view, in which the object of activity not only of social work but in fact of any other assisting profession is taken to be the problem of evil, thus appears to be more general, and therefore also overarching for various concrete conceptions of the object of social work, or objects of work of various assisting professions. This naturally does not mean that various specificities arising from the various origins and various orientation of assisting professions are to be levelled out. Quite on the contrary, the point is that they all share the problem of confronting suffering and evil - along with the fact that their activity consists in assistance, they also share the fact that they are confronted with evil and suffering.

Confrontation with evil, especially such that occurs without cause, is also considered to be a cause of modern protest atheism. When in autumn 1755 Lisbon was destroyed by an earthquake, with over thirty thousand inhabitants dying in the rubble, Leibniz's conception of theodicy was sharply criticized by Voltaire. At least since then suffering of any kind has become an argument for setting in doubt the existence of God with

\footnotetext{
1 This paper is an output of the project of specific research of the Grant Agency of the University of South Bohemia in České Budějovice no. 117/2013/H Conception of quality of social work in connection with self-definition of a social worker and her profession.

2 Or suffering and death as the major forms of evil.

3 Cf. Pavel NAVRÁTIL, Současné pojetí a dilemata disciplíny, in: Základy sociální práce, ed. Oldřich MATOUŠEK, Praha: Portál, 2001 , p. 185.

4 Cf. Silvia STAUB-BERNASCONI, Soziale Arbeit als Handlungswissenschaft, Bern - Stuttgart - Wien: Haupt Verlag, 2007 , pp. 181-182.

5 Cf. Ernst ENGELKE, Die Wissenschaft Soziale Arbeit: Werdgang und Grundlagen, Freiburg i. Br.: Lambertus, 2004, pp. 302-304.

6 Cf. Libor MUSIL, Tři pohledy na budoucnost sociální práce, in: Rizika sociální práce, ed. Martin SMUTEK - Friedrich W. SEIBEL - Zuzana TRUHLÁŘOVÁ, Hradec Králové: Gaudeamus, 2010, pp. 13-15.
} 


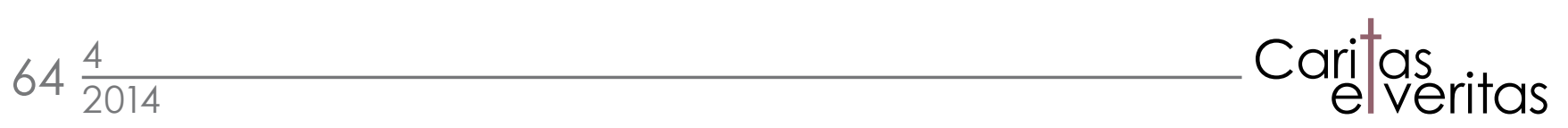

the question 'Where was God when this was happening'.? Thus the question of evil is on the one hand proper to theology and philosophy when they deal with the activity of assisting professions, and on the other hand the problem of evil is associated with doubting the existence of God and faith in him. But the problem is more complex, as Stinglhammer shows on the example of the tsunami of 2004. He points out the paradox that although suffering was called the "rock of atheism" by theorists of atheism in 19th century, the question where God was when something bad happened appears again and again. Rather than set the existence of God definitively in doubt, misfortune and evil raise the question of God again and again. ${ }^{8}$

All members of assisting professions can raise this question and at the same time they can be confronted with it when it is raised by a client. It is therefore useful to ask how the theological view can contribute to assisting professions for several reasons:

a) it is an issue which assisting professions share, as they share the fact of assisting;

b) it is a problem where the assisting profession is by its very activity confronted with existential questions;

c) this existential question may be directly raised by a client.

\section{The concept of evil and its connection to suffering}

In theological context it is common not to distinguish between the concepts of evil and suffering. Already in the Old Testament evil and suffering coincide, since there was no term for suffering in Hebrew. As a result, suffering, i.e., all that human beings suffer, is called "evil". The New Testament uses the Greek word pascho, i.e., to undergo evil - man suffers by undergoing evil. ${ }^{9}$ The fundamental distinction within the phenomenon of evil and suffering is the distinction between necessary and unnecessary. The term 'unnecessary suffering' is used to describe a situation in which - unnecessarily - one human being inflicts evil on another, suffering is considered to be necessary when the evil is not caused by a human - i.e., death in general, natural catastrophes, some diseases, etc. ${ }^{10}$ However, the word "necessary" must not be taken fatalistically in the sense of unavoidable. It is rather the case that this "type" of evil belongs to human existence in this world:

"Human existence comprises not only activity, but also suffering. It arises from our finitude, as well as from the amount of guilt that has accumulated in the course of history and is still increasing now. (...) We must definitely do all we can to overcome suffering. But it is beyond our capacity to eliminate it altogether - for the simple reason that we cannot shake off our finitude and none of us can remove the power of evil, the power of guilt, which still is - as we learn ourselves - a source of suffering. " ${ }^{11}$

\footnotetext{
7 Cf. Hermann STINGLHAMMER, “Die Beste aller Welten?”, Kann man angesichts von Katastrophen noch an einen guten Schöpfer glauben, in: Wo war Gott, als er nicht da war?, ed. Hans MENDL - Ludger SCHWEINHORST-SCHÖNBERGER - Hermann STINGLHAMMER, Berlin: Lit, 2006, pp. 30-31.

8 Cf. ibid., p. 33.

9 The use of the word "pascho" (I am affected by something, I feel, I suffer) for "evil" does not mean objectively the same as pain; it rather expresses a situation in which a human being experiences evil and suffers thereby (cf. Salvifici doloris 7 for more detail).

10 Cf. Jozef TISCHNER, Etika solidarity, München: Opus bonum, 1985, pp. 22-24.

11 Spe salvi 36.
} 
From the Christian point of view, all that humans cannot do with respect to evil can be achieved by God, who in Jesus Christ entered history, became human and together with humans also suffered - experienced evil. ${ }^{12}$

There is therefore nothing strange about asking about the origin of evil. The Christian answer to the problem of evil, as we have shown above, is closely connected with the issue of suffering. A human being experiences suffering whenever she does not share in a good from which she is in some way distant or of which she is deprived. ${ }^{13}$

\section{Assisting professions}

The term "assisting professions" is not univocally defined. Assisting professions are usually taken to be all professions whose theory, research and practice is aimed at assisting others, identifying their problems, and acquiring knowledge of the human being and her life conditions so that assistance can be as effective as possible. ${ }^{14}$ The definition of the concept "assisting professions" is thus very broad. As said above, the main goal is assisting others and solving their problems. The focus of interest of assisting professions is the client as a person with all her roles. ${ }^{15}$ We can thus say that assisting professions is an umbrella concept for a number of professions which have to do with helping people. Assisting professions listed by Kopřiva are doctors, nurses, assistants, educators, social workers, psychologists. He adds, however, that there is an essential element which distinguishes assisting professions from other professions the human relationship between the assisting professional and her client. For, as he goes on to say, the main working tool of someone in an assisting profession is her personality. ${ }^{16}$ Matoušek adopts the classification of assisting professions into so-called grades. In the first grade he lists professions which he expects to be able to directly help people cope with their social and emotional problems. As assisting in so-called second grade he lists professions where the workers deal with clients who find themselves in difficult situations or are undergoing a crisis. In this group he lists, among others, the pastoral professions, ${ }^{17}$ doctors, nurses, teachers, lecturers, as well as police officers, ${ }^{18}$ probation and mediation officers and many others, for, as he says, they are specialists in their professions, but they are also expected to help their clients cope with the social and emotional dimension of their problem situations. ${ }^{19}$

12 Cf. ibid.

13 Cf. Salvifici doloris 7.

14 Cf. Pavel HARTL - Helena HARTLOVÁ, Psychologický slovník, Praha: Portál, 2004, p. 185.

15 Cf. Oldřich MATOUŠEK, Slovník sociální práce, Praha: Portál, 2003, p. 149.

16 Cf. Karel KOPǨIVA, Lidský vztah jako součást profese, Praha: Portál, 1997, p. 14.

17 With respect to the numerous different ways of realizing pastoral work at present we will speak of the 'pastoral professions', which is an umbrella concept for representatives of various churches, as well as ordained ministers of the Catholic Church and lay persons appointed to pastoral work in the Catholic Church.

18 Including the police officer among the assisting professions derives especially from the conception of police work as service to the public. The police serve the public. One of their tasks is to protect the security of persons and property, ensure public order and prevent public crime (cf. § 2 of law no. 273/2008 Sb., on the Police of the Czech Republic). The lawgiver explicitly expresses the fundamental conception of police work as service to the public. Stressing this vocation has to do with implementing a new strategy and philosophy of police work in the style of Community policing, based on a pro-active attitude of the police consisting in taking into account the needs of the community and aimed at establishing an environment of support, trust and mutuality between the police and the public (cf. Antonín FILÁK a kol., Zákon o Policii České republiky s komentárem, Praha: Police history, 2009, p. 9). In comparison to e.g. social work we can state that police work shares some of its general aims, though its orientation is more repressive. This fact is reflected in how it labels the subject of its interest: trespasser $\mathrm{x}$ client (cf. Oldřich MATOUŠEK, Slovník sociální práce, p. 148).

19 Cf. Oldřich MATOUŠEK - Pavel HARTL, Nároky sociální práce a syndrom vyhoření, in: Metody a řízení sociální práce, ed. Oldřich MATOUŠEK, Praha: Portál, 2008, p. 51. 


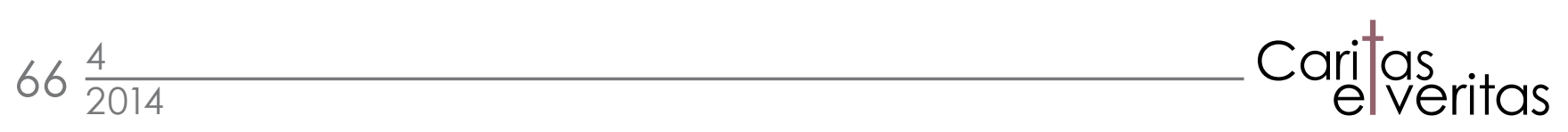

\section{The theological view of evil and suffering}

On some interpretations already the third chapter of the Book of Genesis - the story of the sin of Adam and Eve and their expulsion from Eden - may be read as an attempt to answer the question of evil: "The tree of knowledge symbolizes means and methods whereby human beings individually attempt to attain power over good and evil, a dispositional right to everything, even to humans and to God." ${ }^{20}$ In this way this story seems to contradict the second chapter, which tells how the Lord created humans and set them in the Garden of Eden, where they were to live and which they were to take care of. In fact, this contrast describes the tension between the reality of human life and the good coming from God. The story of Gen 3 attempts to interpret the origin of evil, which it finds in human disobedience to God. This has the catastrophic consequences described by Gen 4 - the story of fratricide. ${ }^{21}$ The story of the tree of knowledge of good and evil is thus a story of attaching oneself to evil and rebellion against God, which can only result in death.

This is also manifest in the dialogue of the Lord with Adam and Eve when they had eaten from the tree of knowledge of good and evil. When God walks through the garden, it means that he is looking for the human being in order to establish communion. But the human hides from him and when he is discovered he blames others, thereby violating the order of creation. There develops a spiral of evil which can only be stopped by God, who talks to the humans and promises to save them, but condemns the serpent without hesitating. The consequence for humans is not only suffering as part of work and bearing children, but especially the futility of their striving as well as efforts to form successful and perfect human relations - the woman will desire the man, but he will not meet her expectations; he will rather govern over her. The mention of leather garments which Adam and Eve receive further explains the origin of the spiral of evil and suffering. As a result of the sin and disobedience of Adam and Eve the order of creation must be violated - animals must be killed in order that their hides cover the uncovered nakedness. That is also the reason why it is beyond human power to return to the original state and it is necessary for God to enter history in Jesus Christ, who brings forgiveness. ${ }^{22}$ The core message of Gen 3 is thus the fact that the present imperfect situation is not the work of God: the suffering of men and women in the course of their life, which the Lord rather states than sets as punishment, does not belong in the order of creation.

The third chapter does not explicitly speak of sin. The Lord "merely" states that now the human being is like him. In the context of the story this means that one cannot be like God without experiencing tension between good and evil. To know good and evil means also to experience their contrast, including the consequence of living outside the Garden of Eden. ${ }^{23}$ Adam's and Eve's nakedness further symbolizes their mortality - they have learned that they are mortal. On Heller's and Prudký's interpretation the cherubs and flaming swords do not guard the entrance to the garden. God leaves it open for humans. What the cherubs and flaming swords do guard, however, is access to the tree of life. The Lord does not allow humans to come and eat from it any more, as Adam and Eve had eaten from the tree of knowledge of good and evil. Overcoming death is thus in God's hands, humans cannot overcome this greatest evil with their own powers. ${ }^{24}$ However, life limited by birth and death is not a deferral of

\footnotetext{
20 STAROZÁKONNÍ PŘEKLADATELSKÁ KOMISE, Výklady ke Starému zákonu: Zákon, vol. I, Praha: Kalich, 1991 , p. 36.

21 Cf. Erich ZENGER, Stuttgarter Altes Testament: Einheitsübersetzung mit Kommentar und Lexikon, Stuttgart: Katholische Bibelanstalt, 2004 , p. 22.

22 Cf. STAROZÁKONNÍ PŘEKLADATELSKÁ KOMISE, Výklady ke Starému zákonu, pp. 36-39.

23 Cf. Erich ZENGER, Stuttgarter Altes Testament, p. 22.

24 Cf. Jan HELLER-Martin PRUDKÝ, Obtížné oddíly knih Mojžíšových, Kostelní Vydří: Karmelitánské nakladatelství, 2006, pp. $28-29$.
} 
punishment, but a unique and unrepeatable opportunity for a human to overcome herself, sin and death with Christ's help. ${ }^{25}$

Another fundamental answer to the problem of evil and suffering is given by the Old Testament Book of Job, which describes the suffering of Job who had never done anything bad. The book is centered around the advice of his three friends on how to cope with it. A basic message of the Book of Job, which can be found towards its end (Job 42:7-17), is that clear, concrete answers attempting to explain - and thus justify - suffering are not much help. At the end of the book God rebukes Job's friends for their irrational advice. At the beginning of the book the correct answer to suffering is shown to be the simple presence of the assistant in the isolation, into which the sufferer is thrown by his suffering. ${ }^{26}$ Similarly, though without direct reference to the Book of Job, the encyclical Spe salvi speaks. ${ }^{27}$ The closing of the Book of Job also shows that the Lord accepts the wailing and reproaches of the sufferer as a human being's adequate answer to the suffering she has gone through, whereas he rejects cheap and simple explanations of the cause of suffering.

The Book of Job sees suffering rather as a trial, when at the beginning it describes how Satan tempts God and asks to be allowed to harm Job, since only when he has ceased to be successful will it be seen if he still trusts God. However, interpreting suffering or evil as a trial or punishment imposed on the human by God is only justified in case the suffering is interpreted as punishment or trial by the one undergoing it. If someone else proposes this interpretation it is in fact a case of cynical attitude to another person's suffering. ${ }^{28}$ In the Book of Job it is precisely Job who interprets the matter in this way, while the way his friends speak about suffering smacks of the cynicism mentioned above.

Another interpretation of evil and suffering experienced by humans based directly on the Bible is punishment. Suffering is divine punishment, or edifying punishment, the purpose of which is to aid improvement. This view derives primarily from the theory of natural law, for which it holds that if the objective moral order has been violated, punishment must follow. However, this does not mean that all suffering is punishment. ${ }^{29}$ The Old Testament statement that God punishes the guilt of fathers on children to the third and fourth generation (Dt 5:9) is frequently employed to justify suffering as punishment for sins. However, already John Chrysostom in the Middle Ages interpreted the statement to cover only cases when the sons are even worse than their fathers and are therefore punished for their own sins. ${ }^{30}$ From the Biblical point of view one cannot deny that suffering and sin are connected. What, however, primarily New Testament texts unambiguously oppose is linking personal suffering to personal sin of the sufferer, as if her suffering were always necessarily punishment for her sins. This also excludes the idea that by suffering someone is punished for the sins of her parents. ${ }^{31}$ Thus although the concept of evil can be used as an umbrella concept for both sin and suffering, this does not express a causal relationship between sin and suffering.

25 Cf. STAROZÁKONNÍ PǨEKLADATELSKÁ KOMISE, Výklady ke Starému zákonu, p. 40.

26 Cf. Adam MACKERLE, Utrpení jako cesta k poznání Boha: K interpretaci knihy Jób, Caritas et Veritas 1/2012, pp. 28-29.

27 Cf. Spe salvi 38.

28 Cf. Hans MENDL, Kinder, Gott und das Leid, in: Wo war Gott, als er nicht da war?, ed. Hans MENDL - Ludger SCHWEINHORST-

SCHÖNBERGER - Hermann STINGLHAMMER, Berlin: Lit, 2006, p. 70.

29 Cf. Salvifici doloris 11-12.

30 Cf. Dominik OPATRNÝ, Ježiš - světlo slepých: Uzdravení slepého od narození ve čtortém evangeliu, Olomouc: UP, 2011, p. 90.

31 Cf. ibid., p. 131. 
Already the story of the Book of Job also shows that interpretations of evil and suffering, which - especially thanks to present more complex knowledge - say that in fact humans are directly (e.g. car crash) or indirectly (e.g. flood) responsible for them, are insufficient. The logical answer to such an argument is why God did not interfere - why he did not change the direction of the car's skidding, why he did not stop the torrent of water, etc. According to Mendl the problem is rooted in an image of God which is infantilized, i.e., God is presented as absolutely good, kind, and positive. This type of answer to suffering uses God to narcotize the sufferer - it tries to trump the power of suffering with a positive God. However, face to face with suffering and evil the positive image of God turns out to be untenable. ${ }^{32}$

Contemporary theology therefore prefers to utilize the cognition of the natural sciences and operates with a thesis labelled "no-better-world". This says, briefly, that the world cannot be better because the universe is a precisely set system of processes, which manifest themselves, among others, by enabling life on Earth - in the highly complex form of human life. This means that a change aimed at making the world better - e.g. so that it would contain no threat of natural catastrophes - might result in threatening the existence of life. A phenomenon that gives rise to a catastrophe at the same time gives rise to conditions suitable for the existence of life. This further means that human efforts to make the world better, so that there would be no catastrophes, may ultimately pose a new threat of life, when they throw the fragile functioning of the Earth out of balance. Ultimately this means that in an evolutionarily developing world purely positive results cannot be reached. According to Stinglhammer, this must be reflected by a revision of the concept of divine omnipotence, which must not be understood in an infantile manner ${ }^{33}$ as the capacity to enforce anything. The concept of divine omnipotence must be corrected: divine omnipotence is a concept belonging to the theology of Christ's cross and Trinitarian theology. God's love for his creation and to the human within it, which is expressed by faith in the Holy Trinity, manifests itself as freedom to surrender, up to the powerlessness of existence, which is the event of the cross. ${ }^{34}$

Naturally, this does not solve the question posed especially in connection with another biblical book, the Gospel of John. The 9th chapter describes how Jesus healed the beggar who had been blind since birth. In the story Jesus' disciples ask why the beggar was blind since birth - a question not posed in connection with the healing miracles of Jesus Christ elsewhere. Jesus rejects connection of suffering (handicap) and sin: "It was not that this man sinned, or his parents, but that the works of God might be displayed in him" (Jn 9:3). But this gives rise to the following question: "Did the man really have to live with such a heavy handicap as a beggar since birth in order for Jesus, or God, to show his power?" 35

When John Chrysostom, whose homilies on the Gospel of John have been preserved complete, explains the suffering of the blind beggar, he starts from the fact that life without sight is better than no life. Since the beggar gained sight, he also gained spiritual vision and his life acquired even greater quality than if he had only gained physical sight. On the other hand, the religious elites who question the healed beggar had physical sight but lost all spiritual vision - as the story further makes clear. ${ }^{36}$ In other words, this point of view in looking for the meaning of suffering ultimately focuses on the conception of value and quality of human life. If human life is an absolute value, an absolute good, then suffering can reduce its quality but does not deny

32 Cf. Hans MENDL, Kinder, Gott und das Leid, pp. 75-76.

33 Cf. ibid., p. 73.

34 Cf. Hermann STINGLHAMMER, “Die Beste aller Welten?”, pp. 38-44.

35 Dominik OPATRNÝ, Ježís - světlo slepých, p. 87.

36 Cf. ibid., p. 90 
its value. The human's task with respect to the value of life is to improve its quality as much as possible. Thomas Aquinas interprets the meaning of suffering in this gospel differently. He assumes that God allows humans to sin in order to transform the evil they commit into good. Thomas believes that the greatest good is one that arose by transformation of evil. That is also why God permits human suffering caused directly or indirectly by no other human, in order to allow for the suffering to give rise to good. On Calvin's interpretation it is a mistake to look for a patent meaning of suffering, since the right thing to do is to look for divine wisdom. ${ }^{37}$

But the Czech translation of the biblical text does not show what is evident in the Greek original, i.e., that Jesus not only denies a causal relationship between sin and suffering, he need not be admitting a causal relationship between suffering and manifestation of God's works, either. (That is probably the reason why the translators of the Czech Ecumenical Translation of the Bible quoted above divided the sentence with Jesus' direct speech with a semicolon.) In other words, the question of the cause or meaning of the beggar's suffering is left unanswered. Instead, Jesus turns the disciples' and readers' attention to the possibilities this suffering presents for the realization of divine purposes and declares that he had been sent to realize them. ${ }^{38}$

The story must also not be taken to mean that suffering and evil entice humans to decide to believe in God. A world that would not contain suffering would be just as ambivalent with respect to the question about God. Even in such world humans would have to or could decide for God or reject him. ${ }^{39}$

That is why contemporary theology does not try to look for the meaning of suffering, but rather focuses on God's solidarity with the suffering human: "Jesus further refuses to speculate on the causes of human suffering; instead, he gives the suffering meaning: he uses it to display the works of God." 40 Suffering acquires meaning by human and divine reaction to it. Here, however, a problem arises concerning God's solidarity with the suffering human, since the teaching that God could suffer was already in antiquity condemned as heretical, since that would imply that evil as the originator of suffering is more powerful than God. But in the Middle Ages a leading reformer of the church Bernard of Clairvaux came up with a wellthought-through expression, which respects the ancient doctrine and formulates the problem more precisely: "Impassibilis est Deus, sed non incompassibilis" ("God cannot suffer, but he can co-suffer"). Benedict XVI. comments on this expression of Bernard's in the following way: "Man is worth so much to God that he himself became man in order to suffer with man in an utterly real way - in flesh and blood - as is revealed to us in the account of Jesus's Passion." ${ }^{41}$ Divine action (actio) is at the same time his suffering (passio). When God acting as creator is affected by the suffering of his creation, he becomes a suffering Creator, who experiences pain. ${ }^{42}$ This idea is eloquently expressed by Jan Neruda in his Passover Ballad. In it the Devil accuses God of cheating on him by sending his Son Jesus Christ to help humans:

"You gave me humanity as a gift for their sin, so that I bind them with sorrow, eternal night, then you took pity on that humanity again and touch the root of my power!" 
God answers the Devil that his Son will have to suffer on the cross and die. The Devil is not satisfied with this and God therefore asks angels to determine how to make Christ's suffering even harder. The angels say that he is to experience the ingratitude of those for whom he dies, further to be betrayed and abandoned by the ones close to him and eventually that he is to die with the feeling that he had been abandoned even by his Father - God. Yet the Devil is still not satisfied and asks more:

"One pain above all pain, one anguish above all anguish -

let the mother stand at the foot of the cross, so that the son would see, how her heart bursts with grief!"

Thus Christ's death on the cross is not just solidarity with the human lot in the sense that the Son of God experiences suffering and death as any other human. The solidarity of God with human suffering consists in compassio - co-suffering: he suffers by the fact that his creation suffers. Already medieval scholastic theology knew the statement: "Quia malum, Deus est" ("Where there is suffering, there is God"). But it understood it to mean that God is not simply in suffering, but that in a No to a concrete evil or suffering the human being meets the good God. ${ }^{43}$ "The question of theodicy is the point of change of faith in God: the infantile God goes into the box with dusty childhood memories, which is a good thing!" 44 From this point of view faith in the Christian God consists in the faith that evil will not have the last say. The experience of suffering can become the experience of the divine God as the deepest dimension of reality. ${ }^{45}$

Christianity (for some perhaps paradoxically) is not a religion that explicitly promises to confer meaning - whether on human life as a whole or on human suffering. It is rather certain conceptions of Christianity, as well as efforts of churches to make themselves "useful and necessary", what gives rise to the impression that the meaning of Christianity as a religion is to give answers to the question concerning the meaning of human life and suffering. Quite on the contrary, Christianity declares first of all the human being's right to be a fragment, to be weak, i.e., the right to imperfection. Already in the Old Testament there were different terms for body, so that depending on the term used it could either signify the human body, or the whole human being, which was meant to express her impermanence resulting from the impermanence of the body. Similarly, the institution of purgatory expresses the conviction that a human being has the right to fail and to redress her failure - even when everything is already definitive, i.e., after death. Finally, Jesus' dealing with humans imperfect in some way, whether bodily or morally, consists in accepting them. In other words, Jesus does not conceive bodily and moral integrity as a measure of normality. The unconditional acceptance of a bodily or morally "imperfect" human being by Jesus Christ becomes an impulse for her to accept herself with her imperfections or weaknesses, which - in case of some moral failures - eventually enables her to redress them. In the case of humans who are ill or handicapped or in case of irrevocable moral failure the acceptance by Jesus brings the human being to accept her own imperfection and weakness, which results in relying on Jesus more than on herself. ${ }^{46}$ 
That is why opinions that a human being must cope with all she encounters in life, including e.g. a bodily handicap or serious disease of her children, are false and inhumane. One cannot even claim that at least a Christian can and must cope with it. In such situations the Christian faith should set the human being free of shame and of the effort to cope with everything alone: Faith should express the human being's awareness of her imperfection ${ }^{47}$ and her hope that God can make good what the human herself was unable to - for what she lacked strength. ${ }^{48}$

\section{Pastoral aspects of assisting professions with respect to evil}

Explaining and justifying suffering and evil as an opportunity to do good may be more problematic than is normally acknowledged, although precisely this justification frequently appears to be most readily acceptable. A human being can do good even without being enticed to it by the evil she encounters. She can ripen morally, personally and religiously even without pain of any kind. Further, the amount of suffering can bring a human being to an attitude of apathy with respect to suffering, which is in fact a form of self-defense, as evident e.g. from war conflict experiences. This does not mean to exclude the fact that encountering evil and suffering mostly inspires humans to help. ${ }^{49}$ With respect to the story of the 9th chapter of the Gospel of John this means that if God wants to act to the benefit of a handicapped human - Jesus heals the blind man in the story - then those who believe in this God are by their faith obliged to help as well - though no miraculous healing can be expected of them: "Born of the mystery of Redemption in the Cross of Christ, the Church has to try to meet man in a special way on the path of his suffering. In this meeting man 'becomes the way for the Church', and this way is one of the most important ones." ${ }^{0}$ The good of the human is in God's interest and thus must also be in the interest of those who believe in God: Disease and handicap are a challenge for humans to act for the benefit of the ill and the handicapped. ${ }^{51}$ However, evil and suffering is in no way explained or justified thereby.

This must be taken into account in the practice of assisting professions. Their work is an answer to the phenomenon of evil and suffering, which does not mean, however, that we can view evil and suffering as something altogether right. As Gen 3 shows, evil and suffering do not belong in the order of creation.

For members of the assisting professions this means that the existential question concerning evil and suffering, whether they ask it themselves or it is presented to them by their clients, may not be answered with simple formulas. This is first of all due to the complexity of the problem, as it has been outlined above, as well as to the contemporary humans' way of thinking in general: "...nowadays 'obedient faith' does not suffice anymore; it must be conceptually replaced by 'understanding faith'; it is not enough to present ready answers and assume that human beings in the postmodern era will adopt them without questioning. They want to understand." 52 That is why members of assisting professions of various orientations ought to engage with the issue of evil and suffering as part of their study and practice. A simple, shortcut answer - whether given to oneself or to another - may evade the problem, which will

47 Cf. Joseph RATZINGER, Úvod do křestanství, Řím: Velehrad, 1982, p. 182.

48 For more detail cf. Michal OPATRNÝ, Právo člověka na nedokonalost jako přispěvek křest́anství k lidským právům, pp. 145-151; Lucie MALIŇÁKOVÁ - Michal OPATRNÝ, Charitativní práce s osobami se zdravotním postižením a pečujícími rodinami, in: Teorie a praxe charitativní práce: Uvedení do problematiky, Praktická reflexe a aplikace, ed. Michal OPATRNÝ - Markus LEHNER, České Budějovice: TFJU, 2010, p. 59.

49 Cf. Hermann STINGLHAMMER, “Die Beste aller Welten?”, pp. 37-38.

50 Salvifici doloris 3.

51 Cf. Lucie MALIŇÁKOVÁ - Michal OPATRNÝ, Charitativní práce s osobami se zdravotním postižením a pečujícími rodinami, p. 58.

52 Hans MENDL, Kinder, Gott und das Leid, p. 70. 
ultimately have to be solved anyway. Looking for answers, though it is difficult, may be an effective reaction to the helper syndrome and prevention of the burn-out syndrome.

Similarly, the most effective help to the client appears to be not evading the existential question, but seeking answers together. Rather than by clever words theology is "transported" by sensitive personal attitudes and concrete solidarity. ${ }^{53}$ So-called spiritual accompaniment is grounded in the faith that God accompanies humans throughout their life and never abandons them, since he is deeply sympathetic with them. ${ }^{54}$ Such faith not only serves as motivation for assisting work; assisting work is first of all to be evidence, witness of the assistant that a human being is not deserted in her suffering - whether by humans or by God. The experience of evil, suffering, and solitude is also an experience of God - Jesus Christ suffering and dying on the cross. This does not hold for pastoral professions alone, it can be analogically applied to members of other assisting professions - whether they profess Christianity or not.

Such witness presupposes acknowledging the special competence of assisting professions' clients, as described by Vanier. ${ }^{55}$ The graver and the more complicated the situation, the greater the competence: Assisting a suffering human forces the assistant to adapt the rhythm of work. She must "slow down the engine of expediency" in order to be able to perceive what the other - even when limited e.g. by a handicap - wants to communicate. Thereby she helps the assistant to learn to perceive the surrounding world as well as himself differently - and at the same time teaches him greater attention for God. ${ }^{56}$ For God cannot be made expedient and the message of Jesus Christ cannot be reduced to inspiring efforts at a better, more humane world. ${ }^{57}$

\section{The Assisting Profession's Confrontation with Evil}

Abstract The paper deals with a common characteristic of the assisting professions which is, besides assisting, also confronting evil. As a result, members of the assisting professions must come to terms with the problem of evil themselves and be able to talk about this existential problem with their clients. The paper therefore deals in detail with the concept of evil and the related concept of suffering, which from the theological point of view is identical with it (to suffer means to experience evil). The paper then reflects on biblical theology and theological development with respect to evil. It concludes that it is fallacious even within theology - to provide definitive answers on the meaning of evil and suffering. An adequate Christian reaction rather seems to be a "theology of action", i.e., practical acting in response to suffering. That implies specific pastoral-assisting competencies of those who "experience evil".

Key words Evil, Suffering, Assisting Professions, Pastoral Care, Social Work, Theodicy

\footnotetext{
53 Cf. ibid., p. 98.

54 Cf. Spe salvi 39.

55 Cf. Lucie MALIŇÁKOVÁ - Michal OPATRNÝ, Charitativní práce s osobami se zdravotním postižením a pečujícími rodinami, p. 61.

56 Cf. Jean VANIER, Rodí se nová naděje: Čím je a má být komunita, Praha: Zvon, 1997, p. 156.

57 Cf. Edward SCHILLEBEECKX, Lidé jako Boží př̌běh, Brno: CDK, 2008, pp. 85-88.
} 